\title{
Necroptosis, a novel form of caspase-independent cell death, contributes to renal epithelial cell damage in an ATP-depleted renal ischemia model
}

\author{
XINLING LIANG ${ }^{1}$, YUANHAN CHEN ${ }^{1}$, LI ZHANG $^{1}$, FEN JIANG ${ }^{2}$, WENJIAN WANG ${ }^{1}$, \\ ZHIMING YE ${ }^{1}$, SHUANGXIN LIU ${ }^{1}$, CHUNPING YU ${ }^{1}$ and WEI SHI ${ }^{1}$ \\ ${ }^{1}$ Department of Nephrology, Guangdong General Hospital, Guangdong Academy of Medical Sciences, Guangzhou, \\ Guangdong 510080; ${ }^{2}$ Department of Nephrology, Central Hospital of Hengyang, Hengyang, Hunan 421001, P.R. China
}

Received August 15, 2013; Accepted April 1, 2014

DOI: $10.3892 / \mathrm{mmr} .2014 .2234$

\begin{abstract}
Acute kidney injury (AKI) induced by renal ischemia is a common clinical problem associated with a high morbidity and mortality. The present study investigated whether necroptosis was present in an in vitro renal ischemia model and whether the addition of necrostatin-1 (Nec-1) has a protective effect. In addition, whether autophagy was inhibited following the use of Nec-1 was also examined. When apoptosis was inhibited by z-VAD-fmk and energy was depleted with antimycin A for $1 \mathrm{~h}$, the morphological abnormalities of human proximal tubular epithelial (HK-2) cells were markedly attenuated, and the cell viability was significantly improved following incubation with Nec-1. LC3-II/I ratios and LC3-II/GAPDH ratios demonstrated a statistically significant decrease in the Nec-1 + tumor necrosis factor (TNF)- $\alpha+$ z-VAD-fmk + antimycin A (1 h) group compared with the control group. In conclusion, the present study suggested that necroptosis was present in HK-2 cells subjected to TNF- $\alpha$ stimulation and energy depletion. Nec-1 inhibits a caspase-independent necroptotic pathway involving autophagy and may have therapeutic potential to prevent and treat renal ischemic injury.
\end{abstract}

\section{Introduction}

Acute kidney injury (AKI) induced by renal ischemia leads to significant morbidity and mortality (1). Studies have suggested that apoptotic, autophagic and necrotic cell death are involved in AKI caused by renal ischemia (2-5). Despite

Correspondence to: Professor Wei Shi, Department of Nephrology, Guangdong General Hospital, Guangdong Academy of Medical Sciences, 106 Zhongshan No. 2 Road, Guangzhou, Guangdong 510080, P.R. China

E-mail: shiweigd139@163.com

Key words: necroptosis, renal ischemia injury, ATP depletion, human proximal tubule cells, necrostatin-1 major advances in the understanding of the molecular mechanisms associated with ischemic AKI, treatment largely remains supportive and outcomes have not improved during the past 50 years (6). Therefore, examining the molecular mechanisms of AKI induced by renal ischemia has become increasingly important.

Cell death was initially divided into apoptosis, autophagy and necrosis according to morphological appearance (7). Apoptosis refers to an active programmed cell death, is executed by intrinsic or extrinsic pathways in response to various cell death stimuli and is regulated by a specific class of compounds, including the caspase cascade (8). Apoptosis is characterized by cell shrinkage, nuclear and cytoplasmic condensation, DNA fragmentation and the formation of apoptosomes (9). Autophagy is an important mechanism to maintain cell homeostasis and provides a pro-survival function under starvation conditions. Distinct from apoptosis, necrosis is considered a passive cell death program and is commonly viewed as an accidental and unregulated event. Necrosis is morphologically characterized by cellular swelling, swelling of organelles, plasma membrane rupture and loss of intracellular contents (10).

A relatively new form of necrosis has been characterized as 'necroptosis' $(11,12)$. Necroptosis is a newly identified type of programmed cell death initiated by the activation of apoptosis induced by binding of tumor necrosis factor (TNF) or Fas to its receptor, referred to as a regulated form of necrosis, which is dependent on the serine-threonine kinase receptor-interacting protein 1 (RIP1) $(13,14)$. Necroptosis exhibits morphological characteristics, which resemble necrosis and can be specifically inhibited by a small molecule, necrostatin-1 (Nec-1), which targets RIP1 (15). As a newly identified form of cell death, intense studies performed in recent years have demonstrated that necroptosis is important in immune system regulation, tissue injury and cellular responses to multiple stresses (16-19).

Necroptosis is a potential therapeutic target for treating numerous diseases. The present study examined whether necroptosis was present in the human proximal tubular epithelial cell line HK-2 following ischemic injury induced by adenosine triphosphate (ATP) depletion and evaluated the effect of Nec-1, an inhibitor of RIP1, which specifically inhibits 
necroptosis, in HK-2 cell injury in an in vitro ATP-depleted renal ischemia model. In addition, the present study assessed whether Nec-1 inhibited autophagy, which is a caspase-independent process activated during necroptosis.

\section{Materials and methods}

Cell culture. HK-2 cells were obtained from the American Tissue Culture Collection (Rockville, MD, USA) and maintained in a mixture of Ham's F12 and Dulbecco's modified Eagle's medium (DMEM:F12; Gibco-BRL, Carlsbad, CA, USA) supplemented with $10 \%$ fetal bovine serum, $100 \mathrm{U} / \mathrm{ml}$ penicillin and $100 \mu \mathrm{g} / \mathrm{ml}$ streptomycin (Gibco-BRL) in a humidified atmosphere of $5 \% \mathrm{CO}_{2}$ and $95 \%$ air at $37^{\circ} \mathrm{C}$. The cells were seeded at an appropriate cell density for different assays and left to grow to $80 \%$ confluence, and then cell synchronization was routinely performed by incubating cells in serum-free medium for $24 \mathrm{~h}$ prior to every experiment. Finally, the cells were exposed to different experimental conditions.

ATP depletion. ATP depletion, an established model of renal ischemia $(20,21)$, was induced by exposing cells to prewarmed glucose-free DMEM that contained the electron transport chain inhibitor antimycin $\mathrm{A}(10 \mu \mathrm{M})$ at $37^{\circ} \mathrm{C}$ in the presence of $5 \% \mathrm{CO}_{2}$ as previously described (22). Glucose removal was required in order to prevent cellular anaerobic glycolysis. The cells were subjected to $30 \mathrm{~min}, 1$ and $2 \mathrm{~h}$ of energy deprivation, respectively.

Cell treatment. Cells were divided into 12 groups as follows: i) Control group: Cells were maintained in DMEM:F12 supplemented with $10 \%$ FBS for 2 h; ii) TNF- $\alpha$ group: Cells were treated with $10 \mathrm{ng} / \mathrm{ml}$ TNF- $\alpha$ (Sigma-Aldrich, St. Louis, MO, USA) for $2 \mathrm{~h}$; iii) TNF- $\alpha+\mathrm{z}$-VAD-fmk group: Cells were treated with $10 \mathrm{ng} / \mathrm{ml} \mathrm{TNF-} \alpha$ and $50 \mu \mathrm{M}$ of $\mathrm{z}$-VAD-fmk (Sigma-Aldrich) for 2 h. iv) TNF- $\alpha+$ z-VAD-fmk + antimycin A (Sigma-Aldrich) group: Cells were treated with $10 \mathrm{ng} / \mathrm{ml} \mathrm{TNF}-\alpha$ and $50 \mu \mathrm{M} \mathrm{z}$-VAD-fmk for $2 \mathrm{~h}$, and with $10 \mu \mathrm{M}$ antimycin $\mathrm{A}$ for $0.5,1$ and $2 \mathrm{~h}$, respectively. v) Nec-1 + control group: Cells were pretreated with $50 \mu \mathrm{M}$ Nec-1 (Cell Signaling Technology, Shanghai, China) for $6 \mathrm{~h}$ and then continuously maintained in DMEM:F12 supplemented with $10 \%$ FBS for $2 \mathrm{~h}$; vi) Nec-1 + TNF- $\alpha$ group: Cells were pretreated with $50 \mu \mathrm{M} \mathrm{Nec}-1$ for $6 \mathrm{~h}$ and then continuously treated with $10 \mathrm{ng} / \mathrm{ml} \mathrm{TNF}-\alpha$ for 2 h; vii) Nec-1 + TNF- $\alpha+$ z-VAD-fmk group: Cells were pretreated with $50 \mu \mathrm{M} \mathrm{Nec}-1$ for $6 \mathrm{~h}$ and then continuously treated with $10 \mathrm{ng} / \mathrm{ml}$ TNF- $\alpha$ and $50 \mu \mathrm{M} \mathrm{z}$-VAD-fmk for $2 \mathrm{~h}$; viii) Nec-1 + TNF- $\alpha+$ z-VAD-fmk + antimycin A group: Cells were pretreated with $50 \mu \mathrm{M}$ of Nec-1 for $6 \mathrm{~h}$ and then continuously treated with $10 \mathrm{ng} / \mathrm{ml} \mathrm{TNF}-\alpha$ and $50 \mu \mathrm{M}$ $\mathrm{z}$-VAD-fmk for $2 \mathrm{~h}$, and with $10 \mu \mathrm{M}$ antimycin A for $0.5,1$ and $2 \mathrm{~h}$, respectively.

Cellular morphological assessment. A phase-contrast inverted microscope and transmission electron microscope were used to survey the changes in cellular morphology. The cells were seeded in $25 \mathrm{~mm}$ culture flasks (Coning Inc., Corning, NY, USA) at a cell density of $10^{5}$ cells. At the end of the incubation period, cells were visualized and images were captured by a phase-contrast inverted microscope (IX71; Olympus, Tokyo, Japan) with a digital camera (Olympus DP72, U-TV0.63XC; Olympus). A transmission electron microscope (JEM-100CX; JEOL Ltd., Tokyo, Japan) was used to observe and capture images of the ultrastructure of cells. The cells were trypsinized and washed with phosphate-buffered saline, and then cell pellets were fixed with $2 \%$ glutaraldehyde in $0.15 \mathrm{mM}$ cacodylate buffer $(\mathrm{pH} 7.2)$ at $4^{\circ} \mathrm{C}$ for $1 \mathrm{~h}$, and washed in $0.15 \mathrm{mM}$ cacodylate buffer ( $3 \mathrm{X} ; 5 \mathrm{~min}$ ). Following that, the cell pellets were fixed in $1 \%$ osmium tetroxide at $4^{\circ} \mathrm{C}$ for $30 \mathrm{~min}$, rinsed with $\mathrm{dH}_{2} \mathrm{O}$ at $4^{\circ} \mathrm{C}$ ( $3 \mathrm{X} ; 2 \mathrm{~min}$ ) and stained with $1 \%$ aqueous uranyl acetate at $4^{\circ} \mathrm{C}$ for $30 \mathrm{~min}$. Finally, cell pellets were dehydrated stepwise with ethanol and embedded in resin (Epon 812) for $12 \mathrm{~h}$. Following $12 \mathrm{~h}$ in the oven at $60^{\circ} \mathrm{C}$ for polymerization, the samples were cut into extremely thin sections $(1 \mu \mathrm{m})$, collected and placed on a small circular metal grid prior to being viewed.

Cell viability assay (CCK-8 assay). HK-2 cells under different experimental conditions were harvested using the Cell Counting kit-8 (CCK-8; Dojindo Laboratories, Kumamoto, Japan) assay to determine the number of viable cells according to the manufacturer's instructions. Briefly, cells were seeded on a 96-well plate at a concentration of $10^{4}$ cells per well and then cells were treated with various experimental conditions as mentioned above. Following incubation, $10 \mu \mathrm{l}$ of CCK-8 solution was added to each well and the 96-well plate was continuously incubated at $37^{\circ} \mathrm{C}$ for $4 \mathrm{~h}$. Then the OD value for each well was read at a wavelength of $450 \mathrm{~nm}$ to determine the cell viability using a microplate reader (Model 550; Bio-Rad, Hercules, CA, USA). The assay was repeated three times. The cell viability was calculated using the following formula: Cell viability $(\%)=$ OD (experiment) - OD (blank) / OD (control) - OD (blank) x 100\%.

Western blot analysis. HK-2 cells under different experimental conditions were lysed in lysis buffer. The total protein concentration from the resultant supernatant was determined by the bicinchoninic acid protein assay (Beyotime Institute of Biotechnology, Nantong, Jiangsu, China). An aliquot of cell lysates containing $30 \mu \mathrm{g}$ of protein were separated by SDS-PAGE and transferred onto a polyvinylidene difluoride membrane (Immobilon-P; Millipore, Billerica, MA, USA) by electroblotting. The membranes were incubated overnight at $4^{\circ} \mathrm{C}$ with rabbit anti-LC3B antibody (L7453; Sigma, St Louis, MO, USA). Following washing, the secondary antibody (Thermo Fisher Scientific, Waltham, MA, USA) was added and incubated for $1 \mathrm{~h}$ at room temperature. The protein bands were visualized by Enhanced Chemiluminescence Plus (Amersham, Arlington Heights, IL, USA) and then exposed to X-ray film (Kodak, Rochester, NY, USA). The bands of the resulting autoradiographs were quantified densitometrically using Bandscan software (version 5.0; Funglyn Biotech, Toronto, ON, Canada). Protein expression was quantified as the ratio of specific band to GAPDH.

Statistical analysis. All values are expressed as the mean \pm standard error. Statistical analysis was performed 
A

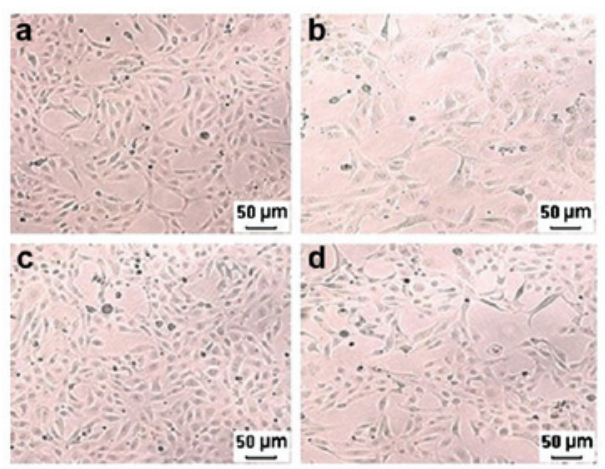

B
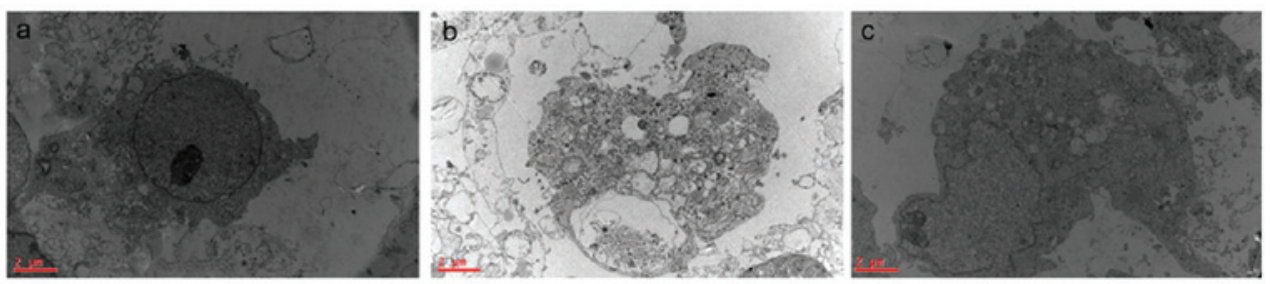

Figure 1. Morphology of HK-2 cells determined by a phase-contrast inverted microscope and a transmission electron microscope. (A) Representative phase-contrast inverted microscope images of HK-2 cells: (a) Control group, (b) TNF- $\alpha+$ z-VAD-fmk + antimycin A (1 h) group, (c) Nec-1 + control group, (d) Nec-1 + TNF- $\alpha+$ z-VAD-fmk + antimycin A (1 h) group (magnification, x100). (B) Representative electron micrographs of HK-2 cells (magnification, x20,000): (a) Control group, (b) TNF- $\alpha+$ z-VAD-fmk + antimycin A (1 h) group, (c) Nec-1 + TNF- $\alpha+$ z-VAD-fmk + antimycin A (1 h) group. Note the prominent nuclear swelling, loss of nuclear condensation and loss of mitochondrial and endoplasmic reticulum mass as hallmarks of programmed necrosis. Bar $=2 \mu \mathrm{m}$. Nec-1, necrostatin-1; TNF- $\alpha$, tumor necrosis factor- $\alpha$.

using the statistical package SPSS for Windows version 13.0 (SPSS, Inc., Chicago, IL, USA). Multiple comparisons among the groups were conducted by one-way analysis of variance with Tukey's tests for post-hoc analysis. $\mathrm{P}<0.05$ was considered to indicate a statistically significant difference.

\section{Results}

Nec-1 and z-VAD-fmk ameliorate morphological abnormality of HK-2 cells following TNF- $\alpha$ stimulation and ATP depletion. ATP depletion is usually applied in in vitro experiments to mimic the renal injury process of ischemia-reperfusion injury (IRI) $(20,21)$. HK-2 cells were treated with $10 \mathrm{ng} / \mathrm{ml} \mathrm{TNF-} \alpha$ and $50 \mu \mathrm{mol} / \mathrm{l} \mathrm{z}-\mathrm{VAD}-\mathrm{fmk}$ for $2 \mathrm{~h}$. Following that, the ATP depleter antimycin A (10 $\mathrm{mM}$ ) was added into the glucose-free medium to incubate the HK-2 cells for different periods of time. Fig. 1A-B shows morphological changes determined by a phase-contrast inverted microscope and a transmission electron microscope, respectively. Fig. 1Aa-d represent the control group, TNF- $\alpha+$ z-VAD-fmk + antimycin A (1 h) group, the Nec-1 + control group and the Nec-1 + TNF- $\alpha+$ z-VAD-fmk + antimycin A (1 h) group, respectively. The morphological abnormalities, including cellular swelling, swelling of organelles and plasma membrane rupture, were significantly ameliorated in the Nec-1 + TNF- $\alpha+$ z-VAD-fmk + antimycin A (1 h) group compared with the TNF- $\alpha+$ z-VAD-fmk + antimycin A ( $1 \mathrm{~h})$ group. Fig. 1Aa-c represents the control group, TNF- $\alpha+$ z-VAD-fmk + antimycin A (1 h) group and the Nec-1 + TNF- $\alpha+$ z-VAD-fmk + antimycin A (1 h) group, respectively. Similarly, these results are also observed using a transmission electron microscope in the

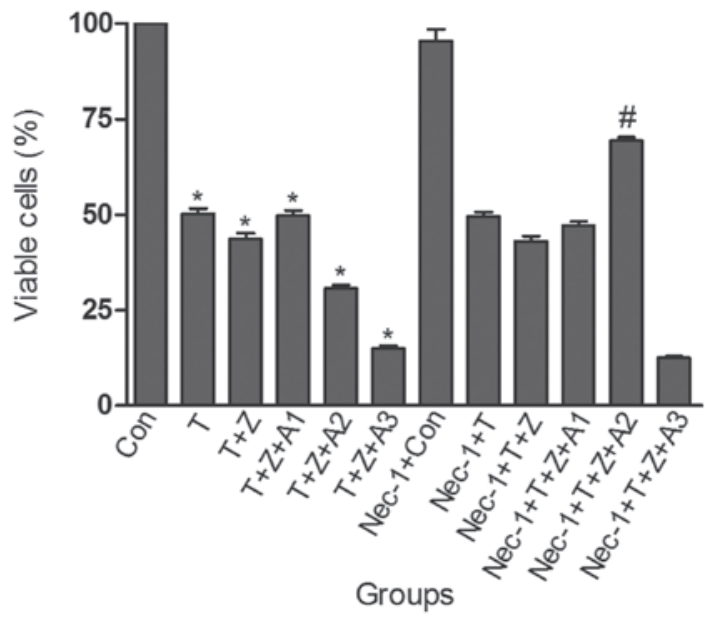

Figure 2. Viability of HK-2 cells measured by the CCK-8 assay and expressed as percentages of the control. Data are expressed as the mean \pm standard error of four independent experiments. ${ }^{*} \mathrm{P}<0.05$ versus control group; ${ }^{\#} \mathrm{P}<0.05$, versus TNF- $\alpha+\mathrm{z}$-VAD-fmk + antimycin A (1 h) group. Con, control group; T, TNF- $\alpha$ group; $\mathrm{T}+\mathrm{Z}$, TNF- $\alpha+$ z-VAD-fmk group; $T+Z+A 1$, TNF- $\alpha+$ z-VAD-fmk + antimycin A (30 min) group; $\mathrm{T}+\mathrm{Z}+\mathrm{A} 2, \mathrm{TNF}-\alpha+\mathrm{z}-\mathrm{VAD}-\mathrm{fmk}+\operatorname{antimycin} \mathrm{A}$ (1 h) group; $\mathrm{T}+\mathrm{Z}+\mathrm{A} 3$, TNF- $\alpha+\mathrm{z}-\mathrm{VAD}-\mathrm{fmk}+\operatorname{antimycin} \mathrm{A}(2 \mathrm{~h})$ group; Nec-1 + con, Nec-1 + control group; Nec-1 + T, Nec-1 + TNF- $\alpha$ group; Nec-1 + T + Z, Nec-1 + TNF- $\alpha+$ z-VAD-fmk group; Nec-1 + T + Z +A1, Nec-1 + TNF- $\alpha+$ z-VAD-fmk + antimycin A (30 min) group; Nec-1 + T + Z + A2, Nec-1 + TNF- $\alpha+$ z-VAD-fmk + antimycin A (1 h) group; Nec-1 + T + Z+A3, Nec-1 + TNF- $\alpha+$ z-VAD-fmk + antimycin A (2 h) group; CCK-8, Cell Counting kit-8; Nec-1, necrostatin-1; TNF- $\alpha$, tumor necrosis factor- $\alpha$.

Nec-1 + TNF- $\alpha+$ z-VAD-fmk + antimycin A (1 h) group compared with the TNF- $\alpha+$ z-VAD-fmk $+\operatorname{antimycin}$ A (1 h) group. 
A
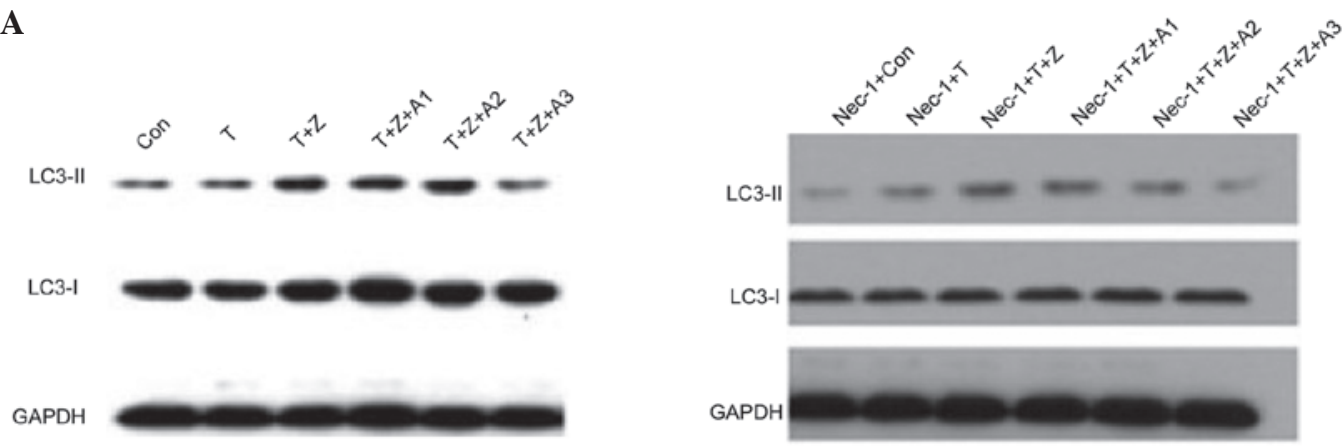

B

C
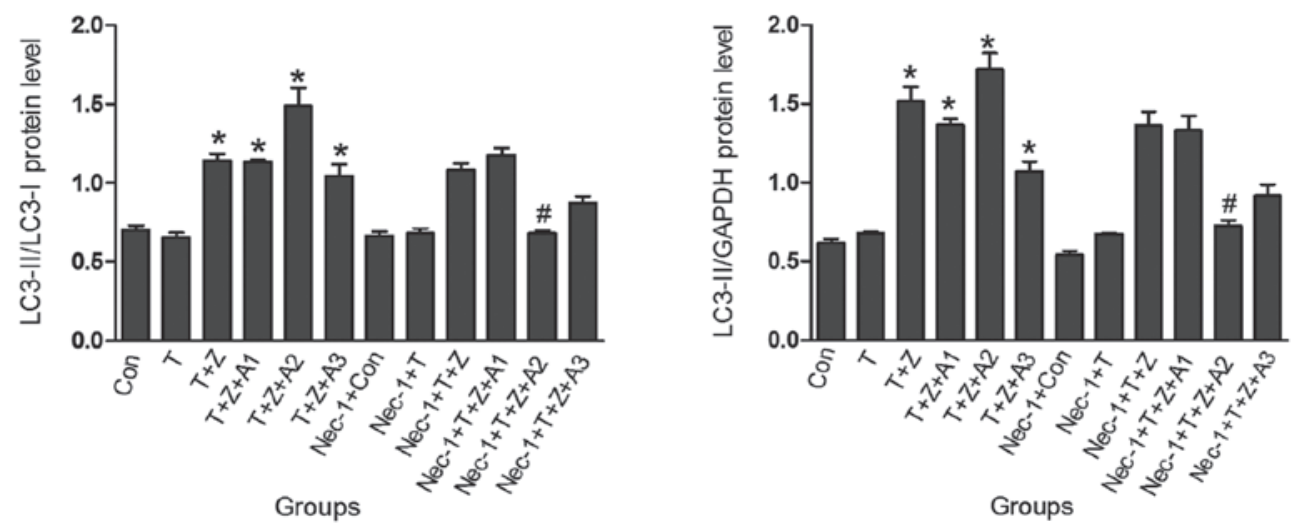

Figure 3. Nec-1 inhibits autophagy following TNF- $\alpha$ stimulation and ischemic renal injury. TNF- $\alpha$ (10 ng/ml) and z-VAD-fmk (50 $\mu \mathrm{M})$ and/or antimycin A1 $(10 \mu \mathrm{M})$ were added for the indicated time periods, and the total cell lysates were prepared and immunoblotted with LC3 and GAPDH antibodies. Blots are representatives of three independent experiments. The protein levels of LC3-I, LC3-II and GAPDH were quantified by densitometry, and LC3-II/I and LC3-II/GAPDH ratios were calculated. " $\mathrm{P}<0.05$, versus control group; ${ }^{*} \mathrm{P}<0.05$, versus TNF- $\alpha+\mathrm{z}$-VAD-fmk + antimycin A (1 h) group. Con, control group; T, TNF- $\alpha$ group; T + Z, TNF- $\alpha+$ z-VAD-fmk group; T + Z + A1, TNF- $\alpha+$ z-VAD-fmk + antimycin A (30 min) group; T + Z + A2, TNF- $\alpha+$ z-VAD-fmk + antimycin A (1 h) group; T + Z + A3, TNF- $\alpha+$ z-VAD-fmk + antimycin A ( 2 h) group; Nec-1 + con, Nec-1 + control group; Nec-1 + T, Nec-1 + TNF- $\alpha$ group; Nec-1 + T + Z, Nec-1 + TNF- $\alpha$ + z-VAD-fmk group; Nec-1 + T + Z + A1, Nec-1 + TNF- $\alpha$ + z-VAD-fmk + antimycin A (30 min) group; Nec-1 + T + Z + A2, Nec-1 + TNF- $\alpha$ + z-VAD-fmk + antimycin A (1 h) group; Nec-1 + T + Z + A3, Nec-1 + TNF- $\alpha$ + z-VAD-fmk + antimycin A (2 h) group; Nec-1, necrostatin-1; TNF- $\alpha$, tumor necrosis factor- $\alpha$; LC-3, protein light chain 3 .

Nec-1 increased cell viability in HK-2 cells following TNF- $\alpha$ stimulation and ATP depletion. As shown in Fig. 2, cell viability was significantly decreased in the TNF- $\alpha$ group $(50.3 \pm 1.4 \%)$, TNF- $\alpha+$ z-VAD-fmk group $(43.7 \pm 1.5 \%)$, TNF- $\alpha+$ z-VAD-fmk + antimycin A (30 min) group (49.7 $\pm 1.4 \%)$, TNF- $\alpha+$ z-VAD-fmk + antimycin A (1 h) group $(30.8 \pm 0.8 \%)$ and the TNF- $\alpha+z-V A D-f m k+$ antimycin A $(2 \mathrm{~h})$ group $(15.1 \pm 0.6 \%)$ compared with the control group $(100 \pm 0.0 \%)$, respectively. Pretreatment with Nec-1 $(50 \mu \mathrm{M})$ had no effect on cell viability in the control group $(95.6 \pm 3.0 \%)$, TNF- $\alpha$ group $(49.5 \pm 1.2 \%)$ and TNF- $\alpha+$ z-VAD-fmk group $(43.0 \pm 1.4 \%)$, respectively. This was apparent by comparison of the Nec-1 + control group $(95.6 \pm 3.0 \%)$ with the control group $(100 \pm 0.0 \% ; \mathrm{P}>0.05)$; the Nec-1 + TNF- $\alpha$ group $(49.5 \pm 1.2 \%)$ with the TNF- $\alpha$ group $(50.3 \pm 1.4 \% ; \mathrm{P}>0.05)$ and the Nec- $1+\mathrm{TNF}-\alpha$ z-VAD-fmk group $(43.0 \pm 1.4 \%)$ with the TNF- $\alpha+z-V A D-f m k$ group (43.7 $\pm 1.5 \%$; $\mathrm{P}>0.05)$. Following treatment with $10 \mu \mathrm{M}$ antimycin A for $0.5,1$ and $2 \mathrm{~h}$, respectively, Nec-1 $(50 \mu \mathrm{M})$ pretreatment significantly increased cell viability from $30.8 \pm 0.8 \%$ (TNF- $\alpha+\mathrm{z}-\mathrm{VAD}-\mathrm{fmk}+$ antimycin A; $1 \mathrm{~h}$ group) to $69.4 \pm 0.8 \%$ (Nec-1 + TNF- $\alpha+$ z-VAD-fmk + antimycin A; $1 \mathrm{~h}$ group; $\mathrm{P}<0.05)$. However, no difference in cell viability in the Nec-1 + TNF- $\alpha+$ z-VAD-fmk + antimycin A (30 min) group $(47.3 \pm 0.9 \%)$ and the Nec-1 + TNF- $\alpha+$ z-VAD-fmk + anti- mycin A (2 h) group $(12.4 \pm 0.5 \%)$ compared with the TNF- $\alpha+$ z-VAD-fmk + antimycin A (30 min) group (49.7 $\pm 1.4 \%)$ and the TNF- $\alpha+\mathrm{z}-\mathrm{VAD}-\mathrm{fmk}+\operatorname{antimycin} \mathrm{A}(2 \mathrm{~h})$ group $(15.1 \pm 0.6 \%$; P $>0.05)$ was observed, respectively, as shown in Fig. 2.

Nec-1 inhibits autophagy following TNF- $\alpha$ stimulation and ATP depletion. In order to further examine the specificity of $\mathrm{Nec}-1$ in renal ischemia HK-2 cells, the present study also assessed whether autophagy, which is a caspase-independent process, is inhibited, and is directly associated with the conversion of the microtubule associated protein light chain (LC)-3 (I) to LC-3 (II). In HK-2 cells subjected to TNF- $\alpha$ and $\mathrm{z}$-VAD-fmk treatment in the presence of ATP depletion for $1 \mathrm{~h}$, it was demonstrated that the changes of the protein levels of the LC3-II/I ratio were significantly increased $(1.49 \pm 0.11$ vs control $0.70 \pm 0.03 ; \mathrm{P}<0.05)$; however, when the cells were pretreated with $\mathrm{Nec}-1$, this increase was markedly inhibited $(0.68 \pm 0.02$ vs $1.49 \pm 0.11 ; \mathrm{P}<0.05)$. Similarly, besides the increase in the LC3-II/I ratio, the LC3-II/GAPDH ratio under Nec-1 treatment was also significantly inhibited in the Nec-1 + TNF- $\alpha+$ z-VAD-fmk + antimycin A (1 h) group $(0.73 \pm 0.03)$ compared with the TNF- $\alpha+$ z-VAD-fmk + antimycin A (1 h) group (1.72 \pm 0.10$)$. No difference in the LC3-II/I 
ratio and LC3-II/GAPDH ratio in the Nec-1 + TNF- $\alpha$ group $(0.68 \pm 0.03,0.67 \pm 0.01), \mathrm{Nec}-1+\mathrm{TNF}-\alpha+\mathrm{z}-\mathrm{VAD}-$ fmk group $(1.08 \pm 0.04,1.36 \pm 0.09)$, Nec-1 + TNF- $\alpha+$ z-VAD-fmk + antimycin A (30 min) group $(1.18 \pm 0.04,1.33 \pm 0.09)$ and the Nec-1 + TNF- $\alpha+$ z-VAD-fmk + antimycin A (2 h) group $(0.87 \pm 0.04,0.9 \pm 0.07)$ was observed compared with the TNF- $\alpha$ group $(0.65 \pm 0.03,0.68 \pm 0.01)$, TNF- $\alpha+z-V A D-f m k$ group $(1.14 \pm 0.07,1.52 \pm 0.09)$, TNF- $\alpha+$ z-VAD-fmk + antimycin A (30 min) group $(1.13 \pm 0.02,1.36 \pm 0.04)$ and the TNF- $\alpha+$ z-VAD-fmk + antimycin A ( 2 h) group (1.04 \pm 0.07 , $1.07 \pm 0.06 ; \mathrm{P}>0.05$ ) respectively, as shown in Fig. 3.

\section{Discussion}

The present study investigated whether caspase-independent cell death (necroptosis) was present in cultured HK-2 cells subjected to energy depletion, and whether the addition of Nec-1, a highly specific receptor-interacting protein kinase 1 inhibitor, improves cell survival following TNF- $\alpha$ stimulation and ATP depletion in an HK-2 ischemic injury model. The present study supports the existence of a novel form of caspase-independent programmed necrosis involving the activation of autophagy in an in vitro model of renal ischemia. Nec-1, a specific inhibitor of necroptosis, increased cell viability in cultured HK-2 cells following TNF- $\alpha$ stimulation and ATP depletion.

AKI induced by renal ischemia is a common clinical complication characterized by an abrupt decrease in the glomerular filtration rate. Despite supportive care, including renal replacement therapy, the five-year mortality rate following AKI remains at $~ 50 \%$ (19). Limited understanding of the cellular mechanisms of AKI complicates the development of an effective treatment. Therefore, examining the molecular mechanisms of AKI has become increasingly important.

Cell death is essential in organ development, tissue homeostasis and degenerative diseases. Three major types of cell death have been described, including apoptosis (23), autophagy (24) and necrosis (25), based on their distinct cell morphology. AKI involves these mechanisms of cell death (2-5). Apoptotic cell death is characterized by the activation of caspases and the formation of apoptotic bodies $(8,9)$, whereas autophagic cell death is differentiated by large-scale sequestration of portions of the cytoplasm in autophagosomes, giving the cell a characteristic vacuolated appearance (26). Distinct from apoptosis, necrosis is morphologically characterized by an early onset of plasma membrane permeabilization, which causes cells to swell and finally rupture, spilling their intracellular contents into the extracellular milieu (10). For numerous years, necrosis was stereotyped as being a form of death occurring in an unregulated manner, resulting from excessive stress. However, an increasing body of evidence from previous years indicated that necrosis may also be executed by regulated mechanisms (13). This regulated non-apoptotic cell death was recently termed necroptosis (11), which is caspase-independent and exhibits the morphological features of necrosis (early membrane and organelle swelling followed by cell lysis). Necroptosis involves Fas/TNF- $\alpha$ death domain receptor activation and inhibition of RIP1 kinase, and it has been suggested that it may contribute to the development of neurological and myocardial diseases $(11,18)$.

In the present study, cell viability was significantly decreased in HK-2 cells following TNF- $\alpha$ stimulation and
ATP depletion. The cell viability decreased in a time-dependent manner. When the cells were pretreated with Nec-1 for $6 \mathrm{~h}$, the cell viability was significantly improved [Nec-1 + TNF- $\alpha+$ z-VAD-fmk + antimycin A (1 h) group, $69.4 \pm 1.7 \%$ vs. the TNF- $\alpha+\mathrm{z}-\mathrm{VAD}-\mathrm{fmk}+\operatorname{antimycin} \mathrm{A}(1 \mathrm{~h})$ group, $30.8 \pm 1.7 \%$; $\mathrm{P}<0.05$ ] in $\mathrm{HK}-2$ cells following the addition of TNF- $\alpha$ and z-VAD, and ATP depletion. This result indicated that necroptosis was present in HK-2 cell injury induced by TNF- $\alpha$ stimulation and energy depletion $(1 \mathrm{~h})$. In the present study, it was noted that Nec-1 pretreatment did not increase cell viability when HK-2 cells were subjected to ATP-depleted ischemic injury for $2 \mathrm{~h}$. This indicated that necroptosis had an early onset and thus drug interventions targeting the mechanisms of necroptosis need to be used as early as possible. In addition, Nec-1 pretreatment did not increase cell viability when HK-2 cells were subjected to TNF- $\alpha$ and z-VAD-fmk treatment. Pretreatment with Nec-1 only demonstrated a protective effect on ATP-depleted HK-2 cells treated with TNF- $\alpha$ and z-VAD-fmk. This may possibly be explained by improved stimulation of the pathogenic background of developing AKI. Similarly, morphological abnormalities, including cellular swelling, swelling of organelles and plasma membrane rupture of HK-2 cells determined by microscopy were markedly attenuated in HK-2 cell ischemic injury following the use of Nec-1. This result further supported the evidence that the presence of necroptosis and Nec-1 had a protective effect on the HK-2 cell ischemic injury model.

In certain studies, necroptosis was characterized by the activation of autophagy, which in turn contributes to cell death (11,27-29). Under conditions of renal ischemic injury, it remains to be elucidated whether necroptosis concomitantly activated autophagy in HK-2 cells. Therefore, the expression levels of LC-3 (II), a marker of autophagy, and the expression change following the use of Nec-1 in HK-2 cell ischemic injury induced by $\mathrm{TNF}-\alpha$ stimulation and energy depletion were investigated. The present study demonstrated that the LC3 II/I ratio was increased in the TNF-a + z-VAD-fmk + antimycin A (1 h) group, while the increased LC3 II/I ratio was markedly inhibited following treatment with Nec-1. Since the ratio of LC3-II to GAPDH is an accurate indicator of autophagy (30), the ratio of LC3-II/GAPDH in HK-2 cells was also analyzed. The treatment with $\mathrm{Nec}-1$ for $1 \mathrm{~h}$ significantly decreased the ratio of LC3-II to GAPDH relative to the control (Nec-1 + TNF- $\alpha+$ z-VAD-fmk + antimycin A group 0.73 \pm 0.03 vs. TNF- $\alpha+$ z-VAD-fmk + antimycin A group 1.72 \pm 0.10 ; $\mathrm{P}<0.05)$. These data closely parallel the activity profile of Nec-1 in necroptotic cells and suggest that Nec-1 targets a caspase-independent necroptotic pathway involving autophagy in vitro.

In conclusion, the present study confirmed that necroptosis, a caspase-independent programmed cell death, is involved in renal epithelial cell damage. For the first time, to the best of our knowledge, the present study revealed that Nec-1 suppressed renal epithelial cell damage in a TNF- $\alpha$-stimulated and ATP-depleted renal ischemia model. In addition, it was noted that Nec-1 targeted a caspase-independent necroptotic pathway concomitantly involving autophagy. The results of the present study suggested that necroptosis may be an important emerging mode of cell death in acute renal ischemia. The therapeutic effects demonstrated with Nec-1 support its use as a novel 
renal-protective agent that targets necrotic cell death mechanisms. The inhibition of necroptosis may be a new strategy for the development of cytoprotective agents in AKI. However, further investigations are required in order to clarify the mechanisms by which necroptosis occurs in AKI.

\section{Acknowledgements}

This study was supported by the National Natural Science Foundation (no. 81170683) and National Key Technology R\&D Program (No. 2011BAI10B08), National Clinical Key Specialty Construction Preparatory Projects.

\section{References}

1. Nash K, Hafeez A and Hou S: Hospital-acquired renal insufficiency. Am J Kidney Dis 39: 930-936, 2002.

2. Havasi A and Borkan S: Apoptosis and acute kidney injury. Kidney Int 80: 29-40, 2011.

3. Jiang M, Wei Q, Dong G, Komatsu M, Su Y and Dong Z: Autophagy in proximal tubules protects against acute kidney injury. Kidney Int 82: 1271-1283, 2012.

4. Padanilam BJ: Cell death induced by acute renal injury: a perspective on the contributions of apoptosis and necrosis. Am J Physiol Renal Physiol 284: F608- F627, 2003.

5. Matsuyama M, Hayama T, Funao K, Naganuma T, Kawahito Y, Sano H, Chargui J, Touraine JL, Nakatani T and Yoshimura R: The effect of neutrophil elastase inhibitor on acute tubular necrosis after renal ischemia-reperfusion injury. Mol Med Rep 1: 489-492, 2008.

6. Ympa YP, Sakr Y, Reinhart K and Vincent JL: Has mortality from acute renal failure decreased? A systematic review of the literature. Am J Med 118: 827-832, 2005.

7. Kroemer G, Galluzzi L, Vandenabeele P, et al: Classification of cell death: recommendations of the Nomenclature Committee on Cell Death 2009. Cell Death Differ 16: 3-11, 2009.

8. Galluzzi L, Joza N, Tasdemir E, Maiuri MC, Hengartner M, Abrams JM, Tavernarakis N, Penninger J, Madeo F and Kroemer G: No death without life: vital function of apoptotic effectors. Cell Death Differ 15: 1113-1123, 2009.

9. Danial NN and Korsmeyer SJ: Cell death: critical control points. Cell 116: 205-219, 2004.

10. Kitanaka $\mathrm{C}$ and Kuchino Y: Caspase-independent programmed cell death with necrotic morphology. Cell Death Differ 6: 508-515, 1999.

11. Degterev A, Huang Z, Boyce M, Li Y, Jagtap P, Mizushima N, Cuny GD, Mitchison TJ, Moskowitz MA and Yuan J: Chemical inhibitor of nonapoptotic cell death with therapeutic potential for ischemic brain injury. Nat Chem Biol 1: 112-119, 2005.

12. Wu W, Liu P and Li J: Necroptosis: an emerging form of programmed cell death. Crit Rev Oncol Hematol 82: 249-258, 2012.

13. Galluzzi L and Kroemer G: Necroptosis: a specialized pathway of programmed necrosis. Cell 135: 1161-1163, 2008.
14. Jin J, Jin X, Qian C, Ruan Y and Jiang H: Signaling network of OSW-1-induced apoptosis and necroptosis in hepatocellular carcinoma. Mol Med Rep 7: 1646-1650, 2013.

15. Degterev A, Hitomi J, Germscheid M, et al: Identification of RIP1 kinase as a specific cellular target of necrostatins. Nat Chem Biol 4: 313-321, 2008.

16. Han J, Zhong CQ and Zhang DW: Programmed necrosis: backup to and competitor with apoptosis in the immune system. Nat Immunol 12: 1143-1149, 2011.

17. Smith CC and Yellon DM: Necroptosis, necrostatins and tissue injury. J Cell Mol Med 15: 1797-1806, 2011.

18. Oerlemans MI, Liu J, Arslan F, den Ouden K, van Middelaar BJ, Doevendans PA and Sluijter JP: Inhibition of RIP1-dependent necrosis prevents adverse cardiac remodeling after myocardial ischemia- reperfusion in vivo. Basic Res Cardiol 107: 270, 2012.

19. Linkermann A, Bräsen JH, Himmerkus N, Liu S, Huber TB, Kunzendorf U and Krautwald S: Rip1 (receptor-interacting protein kinase 1) mediates necroptosis and contributes to renal ischemia/reperfusion injury. Kidney Int 81: 751-761, 2012.

20. Lieberthal W, Menza SA and Levine JS: Graded ATP depletion can cause necrosis or apoptosis of cultured mouse proximal tubular cells. Am J Physiol 274: F315-F327, 1998.

21. Ruchalski K, Mao H, Singh SK, Wang Y, Mosser DD, Li F, Schwartz JH and Borkan SC: HSP72 inhibits apoptosis-inducing factor release in ATP-depleted renal epithelial cells. Am J Physiol Cell Physiol 285: C1483-C1493, 2003.

22. Brooks C, Ketsawatsomkron P, Wang J, Wang CY, Yu FS and Dong Z: Acidic pH inhibits ATP depletion-induced tubular cell apoptosis by blocking caspase-9 activation in apoptosome. Am J Physiol Renal Physiol 289: F410-F419, 2005.

23. Ueda N, Kaushal GP and Shah SV: Apoptotic mechanisms in acute renal failure. Am J Med 108: 403-415, 2000.

24. Tsujimoto Y and Shimizu S: Another way to die: autophagic programmed cell death. Cell Death Differ 12: 1528-1534, 2005.

25. Ha HC and Snyder SH: Poly(ADP-ribose) polymerase is a mediator of necrotic cell death by ATP depletion, Proc Natl Acad Sci USA 96: 13978-13982, 1999.

26. Baehrecke EH: Autophagy: dual roles in life and death? Nat Rev Mol Cell Biol 6: 505-510, 2005.

27. Bell BD, Leverrier S, Weist BM, Newton RH, Arechiga AF, Luhrs KA, Morrissette NS and Walsh CM: FADD and caspase- 8 control the outcome of autophagic signaling in proliferating T cells. Proc Natl Acad Sci USA 105: 16677-16682, 2008.

28. Bonapace L, Bornhauser BC, Schmitz M, Cario G, Ziegler U, Niggli FK, Schäfer BW, Schrappe M, Stanulla M and Bourquin JP: Induction of autophagy-dependent necroptosis is required for childhood acute lymphoblastic leukemia cells to overcome glucocorticoid resistance. J Clin Invest 120: 1310-1323, 2010.

29. Rosenbaum DM, Degterev A, David J, Rosenbaum PS, Roth S, Grotta JC, Cuny GD, Yuan J and Savitz SI: Necroptosis, a novel form of caspase-independent cell death, contributes to neuronal damage in a retinal ischemia-reperfusion injury model. J Neurosci Res 88: 1569-1576, 2010.

30. Klionsky DJ, Abdalla FC, Abeliovich H, et al: Guidelines for the use and interpretation of assays for monitoring autophagy. Autophagy 8: 445-544, 2008. 